\title{
MOŻLIWOŚCI ZASTOSOWANIA AZJATYCKIEGO MODELU ROZWOJOWEGO W WYBRANYCH KRAJACH AZJI POEUDNIOWO-WSCHODNIEJ
}

\section{Wstęp}

Od 1989 r., przyjmowanego za moment narodzin Konsensusu waszyngtońskiego ${ }^{1}$ i rozpoczęcia jego propagowania przez Bank Światowy i Międzynarodowy Fundusz Walutowy, świat został zdominowany przez neoliberalną doktrynę, która nie pozostawia miejsca dla konkurencyjnych nurtów ekonomicznych. Jak udowodnił kryzys finansowy z lat 2007-2009, próba spięcia wszystkich gospodarek świata „złotym kaftanem bezpieczeństwa"2 stanowiła nieudany eksperyment. Stąd w ostatniej dekadzie do łask wracaja poglądy głoszące potrzebę powrotu do (pewnej dozy) wizjonerskiego planowania, niezbędnego przy formułowaniu polityki gospodarczej, zamiast oddawania gospodarek w ręce nieskrępowanego wolnego rynku³. W tym ujęciu interesująca propozycję stanowi azjatycki model rozwojowy, zapoczątkowany przez Japonię pod koniec XIX w., a w pełni wykształcony w powojennych dekadach. Japońska ścieżka rozwojowa stała się podstawą do sformułowania przez Kaname Akamatsu teorii stada lecących gęsi (Flying Geese Paradigm), według której kolejne kraje azjatyckie, zaczynając od Japonii, stawały się naśladowcami technologii produkcyjnych krajów Zachodu - począwszy od przemysłu tekstylnego, poprzez przemysł ciężki, aż do wytwórstwa elektroniki ${ }^{4}$. Obecnie ze względu na trend stopniowej dekarbonizacji gospodarek rozwiniętych, wywołany koniecznością ochrony środowiska, industrializacja staje się uzasadnioną szansą rozwojową dla wielu krajów rozwijających się, w tym m.in. dla uboższych krajów Azji Południowo-Wschodniej.

ORCID: 0000-0003-0681-5668, DOI: 10.4467/23538724GS.20.056.13496

1 Głównymi przesłankami Konsensusu waszyngtońskiego były trzy zalecenia: prywatyzacja i deregulacja gospodarek oraz ograniczanie wydatków budżetowych; zob. N. Klein, Doktryna

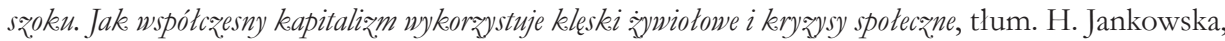
T. Krzyżanowski, K. Makaruk, M. Penkala, Warszawa 2020, s. 198.

2 W ten sposób określono narzucenie na gospodarkę ograniczających zaleceń niedostosowanych do jej specyfiki, obiecując osiagnnięcie wyższego wzrostu gospodarczego; zob. D. Rodrik, The Globalisation Paradox: Democracy and the Future of the World Economy, Oxford 2012, s. 189.

3 G. Kołodko, Dokad zmierza świat. Ekonomia polityczna prayszłości, Warszawa 2013, s. 85.

4 S. Kasahara, The Flying Geese Paradigm: A Critical Study of its Applications to East Asian Regional Development, UNCTAD Discussion Papers 2004, no. 169, s. 3. 
Za okres industrializacji Japonii uznano powojenną dekadę ${ }^{5}$, co zostanie wykorzystane do wysnucia analogii pomiędzy Japonią lat 1950-1960 i współczesnymi gospodarkami wybranych krajów Azji Południowo-Wschodniej.

Głównym celem artykułu jest przełożenie idei azjatyckiego modelu rozwojowego na współczesne realia oraz próba odpowiedzi na pytanie, czy mógłby on zostać wykorzystany przez wybrane kraje Azji Południowo-Wschodniej ze względu na warunki panujące w ich gospodarkach. Realizacji tego celu mają służyć: 1) identyfikacja i przedstawienie założeń azjatyckiego modelu gospodarczego; 2) analiza warunków początkowych pozwalających na zastosowanie modelu azjatyckiego na przykładzie gospodarki powojennej Japonii; 3) ustalenie grupy krajów Azji Południowo-Wschodniej mogących zaadaptować elementy systemu azjatyckiego oraz rekomendacja dotycząca dalszego formułowania polityki gospodarczej z ich wykorzystaniem.

\section{Istota azjatyckiego modelu rozwojowego}

Chcąc przybliżyć istotę azjatyckiego modelu rozwojowego, nie można pominąć specyficznych uwarunkowań historyczno-kulturowych Azji Wschodniej, definiujacych wiele z jego właściwości. Ich najczęściej przytaczaną genezę stanowi okres VI-V w. p.n.e., kiedy na obszarze dzisiejszych Chin nauczał filozof Konfucjusz, głosząc potrzebę osiagnięcia harmonii społecznej. $j^{6}$ Według niego każdy powinien znać swoje miejsce, dążąc przede wszystkim do dobra ogółu, a nie kierować się partykularnym interesem. Na przestrzeni wieków jego nauki zapoczątkowały całą filozofię, która zaczęła wywierać wpływ także poza terytorium państwa chińskiego. To z nauk Konfucjusza, wśród których można znaleźć takie zalecenia, jak lojalność wobec władcy czy szacunek do starszych, wywodzi się wiele cech charakterystycznych dla kultury azjatyckiej, jak wysoka stopa oszczędności czy skłonności kolektywistyczne, idealnie współgrające z założeniami prowadzonej w Azji polityki gospodarczej. Konfucjanizm do tej pory wywiera wpływ na specyfikę funkcjonowania społeczeństw azjatyckich, co można zaobserwować choćby na przykładzie ścisłej hierarchiczności i powszechnego paternalizmu na rynku pracy ${ }^{7}$.

Właściwości azjatyckiego modelu rozwojowego można podzielić na dwie zasadnicze części: kulturową i polityczną (oznaczającą stosowanie konkretnych rozwiązań przy formułowaniu polityki gospodarczej; rozumiana jako policies).

5 Powojenny rozwój Japonii to de facto okres reindustrializacji, jako że przez kilka lat po II wojnie światowej odbudowująca się japońska gospodarka osiagała zaledwie część swojej przedwojennej produktywności. Niemniej, przyjęto takie założenie ze względu na większą dostępność danych statystycznych po $1950 \mathrm{r}$.

6 H. Kissinger, O Chinach, tłum. M. Komorowska, Wołowiec 2017, s. 29-32.

7 G. Redding, Overseas Chinese Networks: Understanding the Enigma, „Long Range Planning” 1995, vol. 28 , no. 1 , s. 61-69. 
Do najważniejszych czynników kulturowych należą: pracowitość, wysoka skłonność do oszczędzania; priorytetowe traktowanie kwestii społecznych, uznanie i szacunek dla władzy; brak zgody na bezwarunkowe przyjmowanie wartości Zachodu oraz pragmatyczne, nieideologiczne podejście do reform ${ }^{8}$.

Główne czynniki polityczne to: polityka makroekonomiczna wspierająca inwestycje; kontrola zagranicznych inwestycji bezpośrednich (dalej: ZIB), ochrona „raczkujących branż” (krajowych, zbyt słabych na konkurencję na arenie międzynarodowej) za pomocą ceł i subsydiów, promowanie eksportu, kontrola konsumpcji dóbr luksusowych? .

W krajach Azji Wschodniej występowała wyraźna spójność obydwu tych sfer, ponieważ wyrastały one ze wspólnego kręgu kulturowego. Nie znaczy to jednak, że inny rodzaj polityki gospodarczej nie zadziałałby w połączeniu z azjatyckimi wartościami lub vice versa. Wszak tak samo jak kultura może mieć wpływ na predyspozycje gospodarki do wyższego (lub niższego) wzrostu gospodarczego, tak czynniki warunkujące rzeczywistość (jak otoczenie prawne czy nawet promowanie określonego stylu życia) moga kształtować nawyki społeczeństwa ${ }^{10}$. Analiza czynników kulturowych zostanie zatem pominięta w niniejszym artykule, który skupi się na czynnikach polityczno-ekonomicznych.

Warto też wspomnieć, że chociaż Korea Południowa i Chiny w dużej mierze wzorowały się na modelu azjatyckim, to poczyniły one w nim pewne modyfikacje, dostosowując jego zalecenia do własnych uwarunkowań. Dlatego nie można traktować ich rozwiązań jako części bazowego modelu, gotowego do przyjęcia i przystosowania przez kraje chcące skorzystać z azjatyckich doświadczeń. Z tego względu za benchmark dla analizowanych krajów Azji Południowo-Wschodniej uznano Japonię.

\section{Analiza warunków początkowych powojennej Japonii}

Ustalając kryteria porównawcze warunków początkowych, trudno nie odnieść się do dzieła jednego z najważniejszych ekonomistów zajmujących się teorią rozwoju, Walta Whitmana Rostowa. Wyróżnił on pięć stadiów rozwoju gospodarczego, zaczynając od gospodarki tradycyjnej, a kończąc na społeczeństwie masowej konsumpcji. Najistotniejszym momentem przełomowym dla gospodarek w jego ujęciu jest „faza startu” (take off) ${ }^{11}$. Choć charakterystyka konkretnych agregatów

8 M. Walkowski, Chinski model rozwoju społeczno-gospodarçego i jego potencjalna adaptacja w Europie, „Przegląd Strategiczny” 2017, nr 10, s. 349.

9 H-J. Chang, The East Asian Development Experience. The Miracle, the Crisis and the Future, London 2007, s. 3.

${ }^{10}$ H-J. Chang, Źli samarytanie. Mit wolnego bandlu i tajna historia kapitalizmu, tłum. M. Sutowski, B. Szelewa, Warszawa 2016, s. 312.

11 W.W. Rostow, The stages of economic growth: A non-communist manifesto, Cambridge 1960, s. 30-37. 
potrzebnych do osiagnięcia tego stadium pozostaje dość mało precyzyjna ${ }^{12}$, to wyznacza ona pewien kierunek rozważań - gospodarki dażące do rozwoju powinny się industrializować poprzez znaczne inwestycje w kluczowe sektory, dobrane przez decydentów politycznych do specyfiki krajowej. Warto zauważyć, że powyższe wytyczne w dużej mierze pokrywają się z najważniejszymi założeniami azjatyckiego modelu rozwojowego.

Historia japońskich doświadczeń rozwojowych wydaje się świetnym przykładem obrazującym teorię Rostowa. Japoński system instytucjonalny zaczął kształtować się już w XIX w. podczas reform Meiji, kiedy ustanowiono prawo do prywatnej własności ziemi, uchwalono spisaną konstytucję oraz powołano parlament w powszechnych wyborach ${ }^{13}$. Proces instytucjonalizacji rozwoju rozpoczęto już w latach 20. XX w. wraz z przyjęciem polityki ograniczania „zbędnej konkurencji” (wasteful competition), pozwalając, a nawet zachęcając do oligo/monopolizacji kluczowych branż produkcyjnych ${ }^{14}$. W okresie przedwojennym $\mathrm{w}$ ramach jednego $\mathrm{z}$ planów pięcioletnich skupiono się na rozbudowie przemysłu ciężkiego, wprowadzając reglamentację surowców i programów produkcji $1^{15}$. W efekcie pomimo przegranej II wojny światowej, w lata 50. XX w. Japonia wkroczyła jako kraj dobrze przygotowany do dalszej industrializacji.

Również współczesne podejście do analizy porównawczej warunków początkowych podkreśla kluczowe znaczenie wyposażenia kraju w czynniki produkcji (w szczególności w kapitał) ${ }^{16}$. Łącząc je ze wskaźnikami pomagającymi skwantyfikować niektóre z założeń modelu azjatyckiego, można zaproponować następujące obszary, które służa porównaniu warunków początkowych państw Azji Południowo-Wschodniej do powojennej Japonii: realne PKB per capita, kapitał na osobę, wydajność kapitału (mierzona jako PKB/kapitał), stopa oszczędności jako \% PKB, inwestycje jako \% PKB, struktura PKB, w szczególności udział sektora przemysłowego, średnia liczba lat edukacji oraz odsetek osób piśmiennych w wieku 15 lat + jako baza dla rozwoju kapitału ludzkiego, wydatki na badania i rozwój (B\&R) jako \% PKB, stanowiące wskazówkę co do potencjału rozwojowego gospodarki, eksport jako \% PKB jako zagadnienie związane z międzynarodowymi stosunkami gospodarczymi niezależne od organizacji międzynarodowych (w przeciwieństwie do np. stawek celnych czy kontroli ZIB).

\footnotetext{
12 Udział inwestycji w PKB wynosi co najmniej 10\%, występuje rozwój sektorów wytwórczych z wysokim wskaźnikiem wzrostu oraz wykształca się system instytucjonalny zdolny do pokierowania rozwojem.

13 D. Acemoglu, J.A. Robinson, Dlaczego narody przegrywaja, tłum. J. Łozinski, Poznań 2014, s. $330-332$.

14 H-J. Chang, Kicking Away the Ladder. Development Strategy in Historical Perspective, London 2005, s. 49.

15 Politykea gospodarcza, red. B. Winiarski, Warszawa 2000, s. 147.

16 P. Kosub, Dlaczego Chiny myprzedzity Indie [w:] Zagadki wzrostu gospodarczego. Sity napedowe i kryzysy - analiza porównawcza, red. L. Balcerowicz, A. Rzońca, Warszawa 2010, s. 281.
} 
Istotny jest też dobór okresu bazowego, do którego porównane zostaną wspó1cześnie rozwijające się kraje. W przypadku Japonii, choć często wspomina się o „powojennym rozwoju", lata 1945-1960 stanowiły w dużej mierze fazę przygotowawczą, kiedy budowano niezbędne struktury instytucjonalne potrzebne do dalszego pokierowania rozwojem ${ }^{17}$. Instytut Badań Ekonomicznych i Społecznych w Japonii potwierdza to spostrzeżenie, uznając, że dopiero od 1955 r. można mówić o rozpoczęciu fazy gwałtownego wzrostu ${ }^{18}$. Z tego względu, chcąc uzyskać pewien kompromis, za okres porównawczy do dalszej analizy przyjąłem średnią agregatów z lat 1950-1960 (tab. 1).

Tab. 1. Wybrane wskaźniki warunków początkowych ${ }^{19}$ Japonii w latach 1950-1960

\begin{tabular}{|r|l|l|}
\hline Lp. & \multicolumn{1}{|c|}{ Wskaźnik } & \multicolumn{1}{c|}{ Wartośćc } \\
\hline 1. & Realne PKB per capita (2011 USD) & 4556,99 USD \\
\hline 2. & Kapitał na osobę (2011 USD) & 10916,28 USD \\
\hline 3. & Wydajność kapitału (PKB/kapitał) & $41,40 \%$ \\
\hline 4. & Stopa oszczędności jako \% PKB & ok. 30 \\
\hline 5. & Inwestycje jako \% PKB & 16,28 \\
\hline 6. & Udział przemysłu w wytwarzanym PKB (\%) & ok. 28-30 \\
\hline 7. & Średnia długość edukacji (w latach) & 11,35 \\
\hline 8. & Odsetek piśmiennych osób w wieku 15 lat + & ok. 99 \\
\hline 9. & Wydatki na B\&R jako \% PKB & 2,0 \\
\hline 10. & Eksport jako \% PKB & 14,26 \\
\hline
\end{tabular}

Źródło: bazy danych: Macrotrends, https://www.macrotrends.net/ (dostęp: 28.12.2020); Penn World Table, https://febpwt.webhosting.rug.nl/ (dostęp: 21.11.2020); Statista, https://www.statista.com/ (dostęp: 28.11.2020); World Bank Open Data, https://data.worldbank.org/ (dostęp: 21.11.2020); także: D.B. Audretsch, H. Yamawaki, R\&D Rivalry, Industrial Policy and U.S.-Japanese Trade, „The Review of Economics and Statistics" 1988, vol. 70, no. 3, s. 441; B. Balassa, M. Nolan, Japan in the World Economy, Washington D.C. 1988, s. 6-7; Measuring Worth, Purchasing Power Calculator, https://www.measuringworth. com/calculators/uscompare/index.php (dostęp: 28.12.2020); Ministry of Finance Japan, Total Value of Exports and Imports (1950-), https://www.customs.go.jp/toukei/suii/html/nenbet_e.htm (dostęp: 28.12.2020); Monbukagakusho, Japanese Government Policies in Education, Culture, Sports, Science and Technology, 2001, Section 1.2, An Ideal of the Constitution and the Fundamental Law of Education; National Institute for Educational Policy Research, Past and Present Education in Japan, https://www.nier.go.jp/English/educationjapan/index.html (dostęp: 28.12.2020); I. Takatoshi, Japan and the Asian Economies: A "Miracle" in Transition, Brookings Papers on Economic Activity 1996, No. 2, s. 212.

17 S.T. Otsubo, Post-war Development of the Japanese Economy, Nagoya 2007, s. 5.

18 S. Yoshioka, H. Kawasaki, Japan's High-Growth Postwar Period: The Role of Economic Plans, ESRI Research Note no. 27, Tokyo 2016, s. 14.

19 Warto podkreślić, że są to warunki początkowe przyjęte na potrzeby artykułu, choć bazuja m.in. na teorii Rostowa, to w jego oryginalnym ujęciu Japonia osiagnęła „fazę startu” już pod koniec XIX w. 
Powyższe dane uznano za punkt odniesienia dla obecnie rozwijających się krajów Azji Południowo-Wschodniej. W dalszej części artykułu skupię się na analizie warunków początkowych wybranych państw na tle Japonii. W ten sposób wyłonione zostaną kraje, które ze względu na podobieństwo w tym zakresie mogłyby zaadaptować azjatycki model rozwojowy jako podstawę do dalszego formułowania polityki gospodarczej.

\section{Przegląd warunków początkowych wybranych krajów Azji Południowo-Wschodniej}

Punktem wyjścia do poszukiwań odpowiednich krajów mogących zaadaptować elementy azjatyckiego modelu rozwojowego będzie ich stosunkowo niski poziom rozwoju społeczno-gospodarczego. Wiąże się to bezpośrednio z głównymi przesłankami modelu - zakłada on przyspieszenie industrializacji kraju, by zapewnić gospodarce podstawy do transformacji w wyższe stadia rozwoju. Z tego względu umowną granica, po przekroczeniu której kraj zostanie uznany za „zbyt rozwinięty", by zakwalifikować się do dalszej analizy, będzie wysokość dochodu narodowego brutto per capita na poziomie ok. 12,5 tys. USD, która według definicji Banku Światowego obejmuje kraje o średnim poziomie rozwoju ${ }^{20}$. Oczywiście wartości dochodu narodowego brutto (DNB) i produktu krajowego brutto (PKB) mogą się między sobą istotnie różnić, jednak ze względu na większą dostępność danych dotyczacych PKB oraz by zapewnić spójność stosowanych metod analizy przyjęto założenie, że ten agregat $\mathrm{w}$ dostatecznym stopniu pokrywa się z definicją Banku Światowego. Dodatkowo, do replikacji modelu azjatyckiego potrzebne jest występowanie odpowiedniej luki rozwojowej, jako że opiera się on w dużej mierze na nadganianiu technologicznym. Po osiagnięciu pewnego poziomu rozwoju wymaga natomiast modyfikacji, by umożliwić transformację gospodarki w bardziej innowacyjną i w mniejszej mierze oparta na przemyśle - w przeciwnym razie kraj może wpaść w tzw. pułapkę średniego dochodu ${ }^{21}$. Proponowana przez badaczy granica, po przekroczeniu której tempo wzrostu gospodarczego zaczyna spadać, wynosi ok. 16,7 tys. USD per capita PPP według cen z $2005 \mathrm{r}^{22}$

Biorąc pod uwage powyższe założenia, w tab. 2. dokonano kwantyfikacji najważniejszych wskaźników charakteryzujących warunki początkowe wybranych krajów Azji Południowo-Wschodniej o wartości PKB per capita PPP nieprzekraczającej 16,7 tys. USD, w odniesieniu do powojennej Japonii. Celem zachowania jednolitej

20 World Bank, Middle Income Countries, https://www.worldbank.org/en/country/mic/overview\#1 (dostęp: 12.12.2020).

21 S. Aiyar, R. Duval, D. Puy, Y. Wu, L. Zhang, Growth Slowdowns and the Middle Income Trap, IMF Working Paper 13/71, International Monetary Fund, Washington DC 2013, s. 3.

22 G. Kołodko, Dokad zmierza świat..., s. 366. 
Tab. 2. Wskaźniki charakteryzujące warunki początkowe wybranych krajów Azji Południowo-Wschodniej w porównaniu z Japonią

\begin{tabular}{|c|c|c|c|c|c|c|c|c|c|}
\hline Lp. & Wskaźnik & $\begin{array}{l}\text { Kambodża } \\
2007-2017\end{array}$ & $\begin{array}{c}\text { Laos } \\
\text { 2007-2017 }\end{array}$ & $\begin{array}{l}\text { Wietnam } \\
\text { 2007-2017 }\end{array}$ & $\begin{array}{l}\text { Filipiny } \\
2007-2017\end{array}$ & $\begin{array}{l}\text { Indonezja } \\
2007-2017\end{array}$ & $\begin{array}{l}\text { Tajlandia } \\
2007-2017\end{array}$ & \multicolumn{2}{|c|}{$\begin{array}{l}\text { Japonia 1950-1960: } \\
\text { przedział }+/-30 \%\end{array}$} \\
\hline 1. & $\begin{array}{l}\text { Realne PKB per capita } \\
\text { (2011 USD) }\end{array}$ & 2716,72 & 5336,75 & 5040,42 & 6254,48 & 9239,53 & 13864,72 & 3189,89 & 5924,09 \\
\hline 2. & $\begin{array}{l}\text { Kapitał na osobę } \\
\text { (2011 USD) }\end{array}$ & 5778,27 & 13737,41 & 13902,39 & 20972,44 & 48187,73 & 62571,42 & 7641,40 & 14191,16 \\
\hline 3. & $\begin{array}{l}\text { Wydajność kapitału } \\
\text { (\% PKB/kapitał) }\end{array}$ & 47,50 & 39,42 & 36,49 & 29,72 & 19,22 & 22,12 & 29,00 & 53,80 \\
\hline 4. & $\begin{array}{l}\text { Stopa oszczędności } \\
\text { jako \% PKB }\end{array}$ & 16,09 & 15,49 & 26,61 & 17,55 & 32,87 & 31,89 & 21,00 & 39,00 \\
\hline 5. & Inwestycje jako \% PKB & 18,17 & 25,19 & 26,14 & 19,14 & 29,15 & 22,30 & 11,40 & 21,20 \\
\hline 6. & $\begin{array}{l}\text { Udział przemysłu } \\
\text { w wytwarzanym PKB (\%) }\end{array}$ & 25,15 & 29,50 & 33,45 & 31,04 & 41,70 & 37,15 & 21,00 & 39,00 \\
\hline 7. & $\begin{array}{l}\text { Średnia długość edukacji } \\
\text { (w latach) }\end{array}$ & 4,50 & 4,94 & 7,88 & 9,13 & 7,72 & 7,59 & 7,94 & 14,75 \\
\hline 8. & $\begin{array}{l}\text { Odsetek piśmiennych } \\
\text { osób w wieku } 15 \text { lat }+\end{array}$ & 77,52 & 71,88 & 94,26 & 96,67 & 93,61 & 94,19 & 69,30 & 100,00 \\
\hline 9. & $\begin{array}{l}\text { Wydatki na B\&R } \\
\text { jako \% PKB }\end{array}$ & 0,12 & b.d. & 0,34 & 0,13 & 0,08 & 0,36 & 1,40 & 2,60 \\
\hline 10. & Eksport jako \% PKB & 59,53 & 35,65 & 80,90 & 29,82 & 24,24 & 68,0 & 9,98 & 18,54 \\
\hline
\end{tabular}

Źródło: opracowanie własne na podstawie baz danych: Macrotrends (dostęp: 28.12.2020); Our World in Data (dostęp: 28.11.2020); Penn World Table (dostęp: 21.11.2020); Statista (dostęp: 28.11.2020); World Bank Open Data (dostęp: 21.11.2020); także: D.B. Audretsch, H. Yamawaki, R\&D Rivalry..., s. 441; B. Balassa, M. Nolan, Japan ..., s. 6-7; Currency Rate, USD to JPY, https://usd.currencyrate.today/jpy (dostęp: 28.12.2020); Measuring Worth, Purchasing...; Ministry of Finance Japan, Total Value...; Monbukagakusho, Japanese Government...; National Institute for Educational Policy Research, Past and Present...; I. Takatoshi, Japan and the Asian..., s. 212. 
metodyki, podobnie jak w przypadku Japonii, wartości uśredniono, bazując na danych z lat 2007-201723.

Szarym wypełnieniem w tabeli zaznaczono względne podobieństwa poszczególnych krajów w danym zakresie w odniesieniu do powojennej Japonii, przyjmując przedział odchyleń 30\% od wartości wyszczególnionych w tab. 1. Choć powyższa analiza obarczona jest pewnym stopniem subiektywizmu, to generalna prawidłowością, która daje się zaobserwować, są zbliżone do Japonii warunki początkowe Wietnamu oraz Laosu. Gospodarka Filipin została wyłączona z dalszej analizy, gdyż pomimo podobieństwa do Japonii w pięciu aspektach, tak jak w przypadku Laosu można zaobserwować względnie większą rozbieżność we wskaźnikach dotyczących kapitału („,za wysoka” wartość kapitału na osobę, przy jednoczesnej niższej wydajności), które uznano tu za decydujące.

\section{Adaptacja modelu azjatyckiego do własnych uwarunkowań na przykładzie Chin}

Poszukując sposobu na określenie możliwości dostosowawczych modelu azjatyckiego do potrzeb poszczególnych gospodarek, warto pochylić się nad przypadkiem Chin. Korzenie „chińskiego systemu ekonomicznego” zdają się sięgać do wielu japońskich rozwiązań ${ }^{24}$, jednak w porównaniu do pierwowzoru poczyniono w nim pewne modyfikacje. Ich szczegółowy przegląd wykraczałby poza zakres artykułu, niemniej warto zwrócić uwagę na przynajmniej trzy z nich, które zostaną przytoczone celem podkreślenia różnic podejścia chińskiego względem oryginału, zwłaszcza że od jakiegoś czasu można spotkać się z potocznym zrównywaniem modelu azjatyckiego z jego chińską adaptacją ${ }^{25}$.

Po pierwsze, w Japonii od lat 50. XX w., mimo istotnej roli państwa w mechanizmach planowania gospodarczego, zasadniczo większość zasobów była dystrybuowana poprzez kanały prywatne. Podstawę industrializującej się gospodarki stanowiły konglomeraty keiretsu, w skład których zazwyczaj wchodził bank lub inna instytucja finansowa, nadzorująca przedsiębiorstwa wewnątrz tej swoistej grupy kapitałowej ${ }^{26}$. Powiązania administracji państwowej z gospodarką przejawiały się najczęściej w postaci niskooprocentowanych kredytów, przydzielania dewiz i ulg

23 Były to najświeższe dostępne dane dotyczące kapitału, realnego PKB i inwestycji w momencie składania artykułu.

24 Występuje m.in. wysoka stopa akumulacji kapitału, długookresowe planowanie strategiczne i bezpośrednia ingerencja w kluczowe dla rozwoju priorytetowe strefy gospodarki oraz wysoki stopień autorytaryzmu i dążenia do harmonii społecznej; zob. E. Cieślik, Rozwój gospodarçyy Chin od roku 1978 do kryzysu globalnego, Warszawa 2015, s. 163-164, 180-181.

25 G. Kołodko, Od ekonomicznej teorii do politycznej praktyki, Warszawa 2020, s. 49.

26 A.W. Ziętek, K. Żakowski, O. Pietrzyk, Polityka zagraniczna Japonii, Lublin 2018, s. 83. 
podatkowych udzielanych jedynie podmiotom podporządkowującym się odgórnym, dobrowolnym zaleceniom ${ }^{27}$. Rząd centralny nie mógł jednak zmuszać przedsiębiorstw do podejmowania pożądanych przezeń działań. Tymczasem Chiny mimo stopniowej liberalizacji gospodarki od lat 80 . wciąż oficjalnie pozostaja gospodarką socjalistyczną ${ }^{28}$. Rozległy sektor państwowy pomimo niższej od prywatnego efektywności jest uważany za pożądany społecznie, ponieważ daje bezpieczeństwo zatrudnienia oraz wpływa na strategiczny rozwój gospodarki ${ }^{29}$. W efekcie udział państwowych przedsiębiorstw w wytwarzanym PKB od początku XXI w. pozostaje na stałym poziomie oscylującym w okolicach $40 \% 0^{30}$, a przedsiębiorstwa prywatne w większości przypadków są finansowane przez państwowe banki komercyjne, co oznacza ich większą zależność od instytucji rządowych ${ }^{31}$.

Po drugie, Chiny charakteryzuje odmienne podejście do międzynarodowych stosunków gospodarczych. Dla rozwijającej się Japonii oraz Korei Południowej zagranica pozostawała przez długi czas jedynie rynkiem zbytu oraz źródłem nowych technologii ${ }^{32}$, podczas gdy napływy kapitałowe oraz towarowe mogły być dowolnie ograniczane. Ówczesny Układ Ogólny w sprawie Taryf Celnych i Handlu (GATT) w przeciwieństwie do zastępującej go od 1995 r. Światowej Organizacji Handlu (WTO) umożliwiał krajom rozwijającym się przyjmowanie szerokiego wachlarza restrykcji i praktyk protekcjonistycznych celem promowania rozwoju lokalnego przemysłu ${ }^{33}$. Chiny natomiast stosunkowo szybko zaczęły stosować się do niektórych zaleceń międzynarodowych organizacji, aby uzyskać przywileje wynikające z przynależności do nich. Przykładowo, zamiast bezpośredniego subsydiowania eksportu masowo skupują dewizy zagraniczne z rynku kapitałowego, nie pozwalając juanowi aprecjonować. W efekcie jednocześnie zwiększaja konkurencyjność eksportu krajowych przedsiębiorstw poprzez zaniżanie kursu walutowego oraz akumuluja pokaźne rezerwy walutowe, możliwe do strategicznego wykorzystania ${ }^{34}$. Według oficjalnych przekazów Chiny starają się także egzekwować międzynarodowe prawa

27 A. Ząbkowicz, Instytucje i wrost gospodarki Japonii, Kraków 2006, s. 21.

28 Choć tak naprawdę trudno jest jednoznacznie zdefiniować realny ustrój gospodarczy Chin, to oficjalne stanowisko Komunistycznej Partii Chin wskazuje na pielęgnowanie „,najważniejszych socjalistycznych wartości w społeczeństwie” i „kierowanie się prawami marksizmu-leninizmu”; zob. E.C. Economy, The Third Revolution. Xi Jinping and the New Chinese State, New York 2018, s. 43; G. Kołodko, Od ekonomicznej teorii..., s. 117.

29 E.C. Economy, The Third Revolution..., s. 112-113.

30 G. Kołodko, Czy Chiny zbawiq śniat?, Warszawa 2018, s. 134-135.

31 S. Heffernan, Nowoczesna bankowość, tłum. J. Horowska, E.M. Kądziela, M. Jankowski, Warszawa 2007, s. 312-313.

32 K.S. Kim, The Korean Miracle (1962-1980) Revisited: Myths and Realities in Strategy and Development, Kellogg Institute Working Paper 1991, no. 166, s. 13.

33 D. Rodrik, The Globalisation Paradox..., s. 198-199.

34 Ibidem, s. 155. 
własności intelektualnej, choć w praktyce są one często łamane i to przy „cichym przyzwoleniu" instytucji państwowych ${ }^{35}$.

Trzecia, prawdopodobnie najistotniejsza różnica objawia się w stosunkach politycznych z zagranica. Podczas gdy Japonia po wojennych upokorzeniach skupiła się na pracy u podstaw, a Korea operowała głównie w sferze czysto handlowej, Chiny zaczynają okazywać coraz większe polityczne ambicje, zwiększając swoje zaangażowanie na arenie międzynarodowej. Już od 2015 r. stały się eksporterami netto kapitału ${ }^{36}$, a od kilku lat można usłyszeć o działaniach związanych z tworzeniem Nowego Jedwabnego Szlaku, którego wymagane nakłady kapitałowe do 2027 r. szacowane są na 1,3 bln USD ${ }^{37}$. Ten stan rzeczy ma oczywiście związek z ekonomią skali, jaka jest w stanie prowadzić Państwo Środka - 1,4 mld mieszkańców stanowiących przeszło 18\% światowej populacji ma możliwość wywierania realnego wpływu na międzynarodowy porządek światowy.

Przykład chiński ukazuje zatem, że możliwe jest dostosowanie azjatyckiego modelu rozwojowego do krajowych uwarunkowań przy zachowaniu jego najważniejszych założeń. Oznacza to, że najprawdopodobniej także Wietnam i Laos mogłyby skorzystać z pewnych jego elementów, by pokierować swoim rozwojem, zamiast zostawiać go w rękach nieskrępowanego wolnego rynku.

\section{Zalecenia dotyczace zastosowania modelu azjatyckiego w Wietnamie i Laosie}

Chcąc przełożyć dotychczasowe rozważania na zalecenia, do których mogłyby zastosować się Wietnam i Laos w swojej polityce gospodarczej, nie można zapomnieć o konieczności ich dostosowania do współczesnych realiów. Tak jak w powojennych dekadach Japonia mogła pozwolić sobie na całkowite zamknięcie się na napływy ZIB, tak w świecie po fali globalizacji w latach 90. nie byłoby to już wykonalne. Podobnie możliwości państw w zakresie formułowania polityki celnej są obecnie bardziej ograniczone - Wietnam i Laos należą bowiem do Stowarzyszenia Narodów Azji Południowo-Wschodniej (ASEAN), którego jednym z celów jest kontynuowanie integracji regionalnej państw członkowskich, m.in. poprzez stopniową eliminację barier celnych ${ }^{38}$. Wydaje się zatem, że wspomniane kraje, aby wdrożyć wybrane elementy azjatyckiego modelu rozwojowego, powinny skupić się na stosowaniu zachęt

\footnotetext{
35 A. Harney, Chińska cena, tłum. J. Mikołajczyk, Katowice 2009, s. 18.

36 Zob. baza danych Trading Economics, https://tradingeconomics.com/ (dostęp: 13.12.2020).

37 D. Tweed, China's New Silk Road, https://www.bloomberg.com/quicktake/china-s-silk-road (dostęp: 13.12.2020).

38 Association of Southeast Asian Nations, Factsheet on ASEAN Economic Community 2019, ASEAN Secretariat, Jakarta 2019, s. 2.
} 
i pozytywnych bodźców zamiast dyskryminacji, kierując i wspierając inwestycje w wybrane branże strategiczne, a także promując ich eksport.

Dodatkową szansą dla krajów chcących rozpocząć rozwój poprzez industrializację jest obecny trend ograniczania emisji $\mathrm{CO}_{2}$ przez kraje rozwinięte. Przykładowo Unia Europejska zgodnie z przyjętym tzw. Europejskim Zielonym Ładem do 2050 r. planuje stać się obszarem o zerowej emisji $\mathrm{CO}_{2}{ }^{39}$, co niechybnie będzie oznaczać przenoszenie części produkcji m.in. do Afryki i Azji Południowo-Wschodniej ${ }^{40}$. Jest to tym bardziej prawdopodobne, że według ustaleń Ramowej konwencji Narodów Zjednoczonych w sprawie zmian klimatu, sporządzonej w Nowym Jorku dnia 9 maja 1992 r. (Dz. U. z 1996 r. Nr 53, poz. 238), kraje rozwijające się nie powinny ponosić taką samą odpowiedzialność za emisję gazów cieplarnianych jak bogate państwa, korzystające z dobrodziejstw paliw kopalnych już od rewolucji przemysłowej $^{41}$. Z tego względu w ciągu najbliższej dekady zapewne będzie można zaobserwować zwiększony napływ inwestycji do wybranych krajów rozwijających się, co przy odpowiednim zarządzaniu procesami globalizacji może stać się dla nich rozwojową szansa.

Jak wynika z tab. 2, Wietnam jest gospodarką najbardziej zbliżoną do powojennej Japonii pod względem warunków początkowych, choć istotną różnicę stanowią jego niewielkie wydatki na badania i rozwój. Przekładają się one na niski odsetek miejsc pracy wymagających wyspecjalizowanych kwalifikacji $(13,5 \%)^{42}$ (knowledge intensive employment). Ogranicza to długoterminowe perspektywy rozwojowe gospodarki, zwiększając ryzyko specjalizacji w sektorach nisko przetworzonych dóbr. Jednocześnie średni czas edukacji oraz odsetek osób piśmiennych wydają się wystarczające jako baza dla dalszego rozwoju kapitału ludzkiego. Oznacza to, że Wietnam powinien dążyć do zwiększania nakładów na B\&R, które są obecnie niedofinansowane. W perspektywie najbliższych kilku lat dobrym punktem odniesienia byłoby osiagnięcie wydatków na B\&R w wysokości przynajmniej 1\% PKB, a docelowo 2\% PKB, co według stanowiska OECD jest poziomem, jaki powinny osiagnąć kraje „aspirujące do dołączenia do grona dojrzałych gospodarek"43. Warto tu także wspomnieć o konieczności dostosowania formy wydatków na B\&R do możliwości danej gospodar-

39 Tożsamą rezolucję przyjęła Japonia; zob. T. Siripala, How will Japan reach its landmark Zero-Carbon Goal?, https://thediplomat.com/2020/11/how-will-japan-reach-its-landmark-zero-carbongoal/ (dostęp: 2.01.2021).

40 G. Kołodko, Od ekonomicznej teorii..., s. 190.

41 N. Klein, To zmienia wszystko. Kapitalizm kontra klimat, tłum. H. Jankowska, K. Makaruk, Warszawa 2020, s. 425.

42 Co plasuje Wietnam na 97. pozycji na świecie pod względem tej statystyki; zob. World Intellectual Property Organisation, Global Innovation Index 2020, https://www.wipo.int/edocs/pubdocs/en/wipo_pub_gii_2020.pdf (dostęp: 2.01.2021).

43 P. Nowak, Rola nydatków na B+R w systemie innowacji w kontekśsie ekonomii umiaru [w:] Ekonomia umiaru: realna perspektywa?, red. J. Pach, K. Kowalska, P. Szyja, Warszawa 2016, s. 379. 
ki - nie wszędzie przyjmą one taką samą formę jak w krajach będących w światowej czołówce rankingów innowacyjności. W przypadku Wietnamu będą to najprawdopodobniej rozwiazzania związane $\mathrm{z}$ rozwojem infrastruktury, imitowaniem zagranicznych technologii, a także learning-by-doing ${ }^{44}$.

W logikę powyższych wniosków wpisuje się także fakt, że choć obecnie przemysł jest najwydajniejszym ze wszystkich sektorów gospodarki Wietnamu ${ }^{45}$, to wciąż opiera się głównie na tekstyliach i przetwórstwie żywności. W tym ujęciu perspektywiczne wydają się poczynione w ciagu ostatniej dekady inwestycje w branże energetyczne, jak wydobycie węgla, produkcja elektryczności czy metalurgia, a także hi-tech w postaci wytwarzania elektroniki ${ }^{46}$. W szczególności branża elektroniczna przykuła uwagę wietnamskich decydentów - w 2016 r. opracowano długoterminową strategie rozwoju gospodarki na lata 2025-2035, a jednym z jej istotniejszych zapisów są specjalne przywileje dla firm decydujących się na inwestycje w zakłady wytwarzające elektronikę ${ }^{47}$. Choć bez wątpienia jest to krok w dobrym kierunku, to branża może zostać zdominowana przez zagraniczne podmioty, skazując Wietnam na rolę dostawcy tanich podzespołów. Wartym rozważenia zabiegiem byłaby więc subsydiowana z budżetu państwa inwestycja i próba stworzenia krajowego podmiotu, który działa w tym zakresie i może wykorzystać know-how spółek zagranicznych ${ }^{48}$, lub zastosowanie odpowiednich zachęt celem zmotywowania krajowych firm do wchodzenia w partnerskie inwestycje typu joint-venture z zagranicznymi korporacjami. Dzięki temu w przyszłości, gdy Wietnam przestanie być konkurencyjny pod względem niskich kosztów siły roboczej, zmniejszy się ryzyko dezinwestycji i odpływu miejsc pracy do krajów o niższym poziomie rozwoju ${ }^{49}$.

44 P. Dobrzanski, S. Bobowski, The Efficiency of R\&D Expenditures in ASEAN Countries, „Sustainability" 2020, vol. 12, no. 4, s. 4.

45 Stosunek udziału w wytwarzanym PKB kraju do odsetka całkowitego zatrudnienia dla przemysłu wynosi 1,21 w porównaniu z 1,17 dla usług oraz 0,39 dla rolnictwa.

46 Nordea Trade, Vietnam: Economic and Political Overview, https://www.nordeatrade.com/en/ explore-new-market/vietnam/economical-context (dostęp: 3.01.2021).

47 Przykładem tego jest m.in. tworzenie specjalnych stref ekonomicznych, mających przyciagnąć inwestorów za pomocą preferencyjnych stawek podatkowych; zob. T. Nguyen, Vietnam's Electronic Industry: A Guide to Emerging Opportunities, https://www.vietnam-briefing.com/news/ vietnams-electronics-industry-guide-emerging-opportunties.html (dostęp: 3.01.2021).

48 Artykuł 10 ustawy o konkurencji z 2004 r. przewiduje zwolnienie podmiotów z odpowiedzialności za wiele działań niosących znamiona nieuczciwej konkurencji, w przypadku gdy ich działalność wspiera konkurencyjność gospodarki Wietnamu na arenie międzynarodowej. Pozwala to domniemywać, że wietnamscy decydenci przewidzieli możliwość wsparcia pewnych branż strategicznych; zob. Association of Southeast Asian Nations, Handbook on Competition Policy and Law in ASEAN for Business 2013, ASEAN Secretariat, Jakarta 2013, s. 76.

49 Jak dotychczas miało to miejsce w krajach Azji Wschodniej i Południowo-Wschodniej, zgodnie z teorią stada lecących gęsi (Flying Geese Paradigm); zob. E. Oziewicz, Development problems 
Wietnam osiagną również bardzo wysokie poziomy wartości eksportu wyrażonego jako \% PKB - w 2019 r. było to już 106,8\% w porównaniu z 29,5\% dla krajów Azji Południowo-Wschodniej oraz 30,5\% dla świata ${ }^{50}$. Choć wielu badaczy wskazuje na dodatnią korelację między wzrostem gospodarczym a eksportem ${ }^{51}$, to nadmierne uzależnienie rozwoju kraju od niego zwiększa podatność gospodarki na zewnętrzne wstrząsy. Przykładowo, w 2018 r. aż 41,7\% całego eksportu Wietnamu pochodziło z jednej branży - elektroniki ${ }^{52}$. Z tego względu dobrym pomysłem mogłaby okazać się dywersyfikacja wachlarza towarów eksportowych. Najlogiczniejszą opcję stanowiłaby branża metalurgiczna - rząd Wietnamu poczynił w niej w ciągu ostatniej dekady znaczne inwestycje, więc przy kontynuowaniu tej polityki realnym celem mogłoby stać się dążenie do stworzenia krajowej spółki na miarę południowokoreańskiego producenta POSCO, mogącej konkurować z największymi producentami stali na arenie międzynarodowej. Za tym pomysłem przemawia także fakt, że Chiny, będące najważniejszym partnerem handlowym Wietnamu ${ }^{53}$, planuja przenieść za granicę część krajowego przemysłu metalurgicznego z powodu narastającego problemu zanieczyszczonego powietrza ${ }^{54}$. Oznacza to pole do negocjacji handlowych w związku z nadchodzącym wzrostem popytu Państwa Środka na stal w najbliższych latach. Dodatkową szansę w tym zakresie stwarza także zawarta w 2020 r. umowa o wolnym handlu między UE a Wietnamem, zwiększając konkurencyjność cenową wietnamskich towarów eksportowych po zniesieniu ce ${ }^{55}$.

Gospodarka Laosu jako druga najbardziej zbliżona pod względem warunków początkowych do powojennej Japonii znajduje się obecnie w nieco innej sytuacji niż Wietnam. Pomimo wyższego średniego PKB per capita poziom rozwoju kapitału ludzkiego jest zdecydowanie niższy (zob. tab. 2), co objawia się wysokim odsetkiem analfabetów (prawie 30\%) oraz krótką średnią długością edukacji, nieprzekraczająca 5 lat. Oznacza to potrzebę nadania innych priorytetów na tym polu niż w przypadku Wietnamu - zwiększanie nakładów na B\&R (których, co znamienne, nie uwzględnia się nawet w statystykach) nie zda się na wiele w obliczu niedoboru wykwalifikowanej kadry. Celem Laosu powinno za to stać się zwiększenie wydatków na edukację -

of the Southeast Asian economies, „International Journal of Emerging and Transition Economies” 2010, vol. 3 , no. 1 , s. 5 .

50 Zob. baza danych World Bank Open Data (dostęp: 4.01.2021).

51 Szczegółowe zestawienie wyników wielu empirycznych badań na ten temat zob. P. Śliwiński, Przeplyny kapitału miedzynarodowego a wrost gospodarcay w krajach Europy Środkowo-W schodniej w latach 1994-2008, Poznań 2011, s. 215-216.

52 Zob. baza danych OEC (dostęp: 4.01.2021).

53 W 2018 r. do Chin trafiło 19,6\% całkowitego eksportu Wietnamu, zob. ibidem.

54 E.C. Economy, The Third Revolution..., s. 183.

55 Warto zwrócić uwage na efekty analogicznej umowy zawartej między USA i Wietnamem w 2001 r. - wartość wietnamskiego eksportu do Stanów Zjednoczonych wzrosła wtedy czterokrotnie w ciagu 2 lat; zob. E. Oziewicz, Southeast Asian Economies and a New Regionalism, „Krakowskie Studia Międzynarodowe” 2006, nr 1, s. 95. 
w 2020 r. wyniosły one zaledwie równowartość 2,9\% PKB w porównaniu z 4,2\% dla Wietnamu oraz 4,1\% dla krajów Azji Południowo-Wschodniej ${ }^{56}$. Dobrym punktem odniesienia mogłoby więc stać się ich zwiększenie do poziomu 4\% PKB do 2030 r. W efekcie na przestrzeni nadchodzącej dekady odsetek piśmiennych osób powinien wzrosnąć przynajmniej do $80 \%$, a średni czas edukacji wydłużyć się do 6 lat. W przyszłości uzasadniłoby to dążenie do osiągnięcia wydatków na B\&R w równowartości 1\% PKB.

Kolejnym czynnikiem ograniczającym możliwości rozwojowe gospodarki Laosu jest niska konkurencyjność krajowych przedsiębiorstw. Ma to związek z niewielka, średnio 15\% stopą oszczędności brutto, co utrudnia akumulację kapitału i uzależnia inwestycje od zagranicznych przedsięwzięć. Nie pomaga także fakt, że rodzimi przedsiębiorcy napotykają dodatkową barierę w postaci nadmiernej biurokracji i braku wsparcia ze strony państwa podczas zakładania firm. Średni czas potrzebny na założenie spółki z o.o. w Laosie wynosi 173 dni, w porównaniu z 25 dniami dla średniej Azji Południowo-Wschodniej ${ }^{57}$. Z tego względu dla decydentów Laosu w tym zakresie priorytetem powinny stać się dwa zagadnienia. Po pierwsze, należy promować wyższą stopę oszczędności wśród społeczeństwa. Choć płynąca ze strony państwa argumentacja powinna zostać dokładniej dookreślona, to na pewno warto wspomnieć o nadchodzącym zapotrzebowaniu kapitałowym i chęci częściowego uniezależnienia gospodarki od zagranicznego finansowania, co istotnie poprawi sytuację krajowych przedsiębiorstw. Celem powinno stać się osiągnięcie średniorocznej stopy oszczędności w wysokości 20-25\% do 2030 r. Po drugie, równolegle należy uprościć proces zakładania działalności gospodarczej. Choć intuicyjnym sposobem mogłaby wydawać się ogólna deregulacja procesów biurokratycznych, to na początku warto zastanowić się nad promowaniem wybranych branż, w których proces zakładania firm zostanie uproszczony, a ze strony państwa przedsiębiorcy będą mogli oczekiwać wsparcia w postaci ulg podatkowych i/lub subsydiów. Strategia rozwoju Laosu na lata 2020-2025 wskazuje pięć kluczowych sektorów ${ }^{58}$, które stanowią dobry punkt wyjścia do przeprowadzenia wspomnianych reform.

Istotnym problemem jest też nadmierna zależność gospodarki Laosu od eksportu surowców $^{59}$ oraz wysoki strukturalny deficyt rachunku obrotów bieżących - te dwie

\footnotetext{
56 Zob. World Intellectual Property Organisation, Global Innovation...

57 Między innymi dlatego Laos plasuje się na 181. miejscu ze 190 pod względem łatwości rozpoczęcia działalności gospodarczej; zob. World Bank, Doing Business 2020, https://www.doingbusiness.org/en/reports/global-reports/doing-business-2020 (dostęp: 5.01.2021).

58 Są to: przetwórstwo żywności i drewna, tekstylia, rzemiosło oraz technologie informacyjne; zob. Economic Research Institute for ASEAN and East Asia, Development Strategy of Five Selected Sectors in the Lao People's Democratic Republic (2020-2025), ERIA Research Project Report 2018, no. 07 .

59 W 2018 r. nieprzetworzone minerały stanowiły przeszło 40\% całkowitego eksportu kraju; zob. baza danych OEC (dostęp: 6.01.2021).
} 
składowe oznaczają duża podatność na wahania cen surowców oraz cykliczność koniunktury ${ }^{60}$. Poprawa tego stanu rzeczy może przebiegać dwutorowo. Po pierwsze, sektor wydobywczy w Laosie jest zdominowany przez zagraniczne podmioty, co wymusza nadmierną specjalizację kraju w eksporcie surowców. W związku z tym zasadne wydaje się wprowadzenie pewnych ograniczeń, dotyczących otwierania nowych kopalni przez zagraniczne koncerny. Wartym rozważenia rozwiązaniem mógłby okazać się wzorowany na krajach Ameryki Lacińskiej wymóg reinwestowania części zysków w kraju jako zadośćuczynienie za wyrządzane szkody środowiskowe ${ }^{61}$ lub konieczność sprzedaży pewnej części wydobywanych surowców do krajowych przedsiębiorstw, co w dalszej perspektywie pozwoliłoby zdywersyfikować wachlarz towarów eksportowych o stal i inne wyroby metalowe ${ }^{62}$. Wiąże się to bezpośrednio z drugim obszarem działań, polegającym na rozwoju krajowego sektora energetycznego. Laos w najbliższej dekadzie powinien dążyć do stworzenia silnego sektora metalurgicznego celem ograniczenia ilości surowców przeznaczonych na eksport, w ten sposób zwiększając wartość dodaną wypracowywaną w kraju. Obszarem godnym uwagi jest także przetwórstwo ropy naftowej, jako że w 2018 r. stanowiła ona 15\% całkowitego importu Laosu ${ }^{63}$. Słuszną decyzja jest zatem rozpoczęcie prac nad pierwsza w kraju rafineria ${ }^{64}$ - w przyszłości warto kontynuować inwestycje w podobne obiekty celem redukcji konieczności importu ropy. Rozwój sektora energetycznego w Laosie oznacza więc potencjał redukcji importu kraju nawet do $25 \%$, przyszłościowo umożliwiając także rozpoczęcie eksportu nadwyżek surowców energetycznych. Oznaczałoby to możliwość przejścia z obecnego 7\% deficytu handlowego na kilkuprocentową nadwyżkę, znacznie zmniejszając podatność gospodarki na zewnętrzne wstrzasy i fluktuacje cen surowców.

\section{Podsumowanie}

W artykule zgodnie z założonymi celami badawczymi przedstawiono istotę azjatyckiego modelu gospodarczego oraz dokonano kwantyfikacji wybranych wskaźników dotyczących warunków początkowych powojennej Japonii lat 1950-1960. Umożliwiło to porównanie do niej sytuacji gospodarczej współczesnych krajów

\footnotetext{
${ }^{60}$ Zob. Coface, Economic Studies and Country Risks: Laos, https://www.coface.com/Economic-Studies-and-Country-Risks/Laos (dostęp: 6.01.2021).

${ }^{61}$ N. Klein, Doktryna szoku..., s. 83.

${ }^{62}$ W krótszej perspektywie miałoby to pozytywny wpływ na saldo bilansu handlowego, jako że w 2018 r. 10\% całkowitego importu Laosu stanowiła stal i wyroby stalowe; zob. baza danych OEC (dostęp: 6.01.2021).

63 Zob. ibidem.

64 R. Brelsford, Laos commissions first oil refinery, https://www.ogj.com/refining-processing/refining/operations/article/14188970/laos-commissions-first-oil-refinery (dostęp: 6.01.2021).
} 
Azji Południowo-Wschodniej. Przyjmując 30\% zakres odchyleń od wartości wskaźników dla Japonii, za gospodarki o względnie podobnych warunkach początkowych uznano Wietnam i Laos. Przedstawienie sposobu dostosowania modelu azjatyckiego do własnych uwarunkowań przez Chiny zapewniło punkt odniesienia i umożliwiło opracowanie zaleceń dotyczących formułowania polityki gospodarczej z wykorzystaniem jego elementów dla Wietnamu i Laosu, które zostały zwięźle zaprezentowane w tab. 3.

Tab. 3. Propozycja zaleceń dotyczących formułowania polityki gospodarczej dla Wietnamu i Laosu z zastosowaniem elementów azjatyckiego modelu rozwojowego

\begin{tabular}{|c|c|}
\hline Wietnam & Laos \\
\hline $\begin{array}{l}\text { Zwiększenie wydatków na } \\
\text { B\&R, mające na celu osiagnięcie } \\
\text { równowartości } 1 \% \text { PKB do } \\
2025 \text { r. oraz } 2 \% \text { do } 2030 \text { r. }\end{array}$ & $\begin{array}{l}\text { Zwiększenie wydatków na edukację do równowartości } \\
\text { 4\% PKB do } 2030 \text { r., by podnieść do } 80 \% \text { odsetek osób } \\
\text { piśmiennych oraz ustalić średni czas edukacji na } 6 \text { lat. } \\
\text { Przyszłościowo należy dąźć do osiagnięcia wydatków } \\
\text { na B\&R w wysokości } 1 \% \text { PKB }\end{array}$ \\
\hline $\begin{array}{l}\text { Stworzenie subsydiowanego } \\
\text { z budżetu państwa } \\
\text { przedsiębiorstwa do } 2030 \mathrm{r} \text {. } \\
\text { i/lub zachęcanie krajowych } \\
\text { przedsiębiorców do inwestycji } \\
\text { w branży elektronicznej }\end{array}$ & $\begin{array}{l}\text { Osiagnięcie stopy oszczędności w wysokości } \\
20-25 \% \text { PKB do } 2030 \text { r. Uproszczenie procesu } \\
\text { zakładania firm oraz wsparcie przedsiębiorstw } \\
\text { w kluczowych branżach }\end{array}$ \\
\hline $\begin{array}{l}\text { Kontynuacja inwestycji w branżę } \\
\text { energetyczną oraz metalurgiczną, } \\
\text { by udział stali, ropy i innych } \\
\text { surowców energetycznych } \\
\text { w całkowitej wartości eksportu } \\
\text { kraju do } 2030 \text { r. wyniósł } 10-20 \%\end{array}$ & $\begin{array}{l}\text { Wymóg reinwestycji przez zagranicznych inwestorów } \\
\text { części zysków i/lub sprzedaży części surowców } \\
\text { krajowym przedsiębiorstwom dla nowo zakładanych } \\
\text { kopalni. Rozwój branży metalurgicznej i energetycznej, } \\
\text { mający na celu stopniowe zastępowanie importu } \\
\text { surowców energetycznych krajową produkcją i wyjście } \\
\text { z deficytu bilansu handlowego do } 2030 \mathrm{r} \text {. }\end{array}$ \\
\hline
\end{tabular}

Źródło: Opracowanie własne.

Powyższe rekomendacje nie pretendują do miana najlepszych możliwych rozwiązań dla wspomnianych krajów, lecz mają na celu podkreślenie kierunku rozważań, który warto przyjąć, formułując politykę gospodarczą. Pozostawiają one jednocześnie pole do dalszej dyskusji. Warto także zauważyć, że zaproponowane działania wpisuja się w już istniejący sposób prowadzenia polityki gospodarczej Wietnamu i Laosu, co pozwala domniemywać, iż kraje te dostrzegły potencjał w wykorzystaniu elementów azjatyckiego modelu rozwojowego.

Podsumowując, najważniejszą kwestią pozwalającą wysnuć analogię do azjatyckiego modelu rozwojowego pozostaje długoterminowe planowanie strategiczne w formie bezpośredniej ingerencji w strefy gospodarki uznane przez krajowych decydentów za kluczowe dla rozwoju. W przypadku Wietnamu za kluczowe można 
uznać branżę elektroniczną i energetyczną, a w Laosie metalurgiczną i energetyczna. Wysoka stopa oszczędności wraz z promowaniem eksportu stanowią komplementarne elementy takiej polityki, podczas gdy kontrola ZIB oraz cła sa już obecnie względnie mniej użytecznymi narzędziami. Ważną sfera, wymagającą modyfikacji w zależności od krajowych uwarunkowań, są także wydatki na B\&R - zarówno jeśli chodzi o wysokość nakładów, jak i sposób ich wykorzystania. W przypadku mniej rozwiniętych gospodarek (jak np. w Laosie) powinny one w dużej mierze zostać wykorzystane w rozwoju infrastruktury i imitacji zagranicznych technologii.

\section{SUMMARY}

\section{THE APPLICABILITY OF THE ASIAN DEVELOPMENT MODEL IN SELECTED SOUTHEAST ASIAN COUNTRIES}

The aim of this article was to analyze the applicability of the Asian development model in selected Southeast Asian countries. The presentation of the main assumptions of the model together with an analysis of the initial conditions of Japan from 1950-1960 allowed for a comparison, of which the conclusion was the relative similarity of Vietnamese and Laotian economies to post-war Japan. Next, the case study of China's policies endeavoured to highlight the adaptability of the model to domestic specifities. Henceforth, the article aimed at formulating policies featuring the usage of Asian development model, which could be implemented by Vietnam and Laos. Its main conclusion was the observation, that after adjusting certain assumptions of the model to domestic conditions, it still remains an attractive alternative for countries wishing to pursue development through industrialisation. 